\title{
Response of Vitis vinifera L. cv. Merlot to Low Frequency Drip Irrigation and Partial Root Zone Drying in the Western Cape Coastal Region - Part I. Soil and Plant Water Status
}

\author{
P.A. Myburgh \\ ARC Infruitec-Nietvoorbij ${ }^{1}$, Private Bag X5026, 7599, Stellenbosch, South Africa
}

Submitted for publication: October 2010

Accepted for publication: November 2010

Key words: Grapevine, subsurface drip, lateral flow, water constraints, water potential

\begin{abstract}
The impact of five drip irrigation strategies on water status in Merlot/99R was compared to a non-irrigated control (T1) in the coastal wine grape region of the Western Cape province, South Africa. Relationships between predawn $\left(\Psi_{\mathrm{PD}}\right)$, leaf $\left(\Psi_{\mathrm{L}}\right)$, stem $\left(\Psi_{\mathrm{S}}\right)$ and total diurnal $\left(\Psi_{\mathrm{Tot}}\right)$ water potential made it possible to classify grapevine water status in terms of $\Psi_{\mathrm{L}}, \Psi_{\mathrm{S}}$, or $\Psi_{\mathrm{Tot}}$ according to previous classifications derived from $\Psi_{\mathrm{PD}}$. Around véraison, T1 grapevines already experienced moderate to strong water constraints $\left(\Psi_{\mathrm{S}}<-1.0 \mathrm{MPa}\right)$, followed by strong to severe water constraints $\left(\Psi_{\mathrm{S}}<-1.4 \mathrm{MPa}\right)$ prior to harvest. Irrigations at pea size, véraison and post-harvest, either applied in grapevine rows (T2) or work rows (T4), did not reduce water constraints compared to $\mathrm{T} 1$. However, irrigations at pea size, midway between pea size and véraison, at véraison, midway between véraison and harvest, and post harvest, either applied in grapevine rows (T3) or work rows (T5), reduced grapevine water constraints compared to $\mathrm{T} 1$. Irrigation in work rows did not affect grapevine water status compared to irrigation in grapevine rows. A partial root zone drying (PRD) strategy, obtained by switching subsurface irrigation in work rows between alternating rows at approximately 14-day intervals (T6), also reduced water constraints compared to $\mathrm{T} 1$. The water status in PRD grapevines clearly responded to the low plant available water (PAW) depletion levels in the alternating work rows in which irrigations were applied. There was minimal lateral flow of irrigation water from subsurface irrigation lines in the work rows towards the grapevine rows.
\end{abstract}

\section{INTRODUCTION}

The Western Cape province has a Mediterranean climate with long, dry summers, during which almost no flow occurs in the major river systems. Consequently, irrigation water is a limited resource. Some of the winter rainfall is retained in storage dams, but in most cases agriculture has to compete with urban and industrial needs for this water. Due to the restricted availability of irrigation water, many wine grapes are grown non-irrigated, i.e. rain fed. Vineyards in the coastal wine grape region are irrigated primarily using water from boreholes and/or winter rainfall that is stored in relatively small, on-farm storage dams. Depending on water availability, vineyards are irrigated at low frequencies, i.e. between one and six irrigations from bud break in September until the post-harvest period in April.

Irrigation reduces water constraints in grapevines in comparison to non-irrigated ones (Van Zyl \& Weber, 1981; Myburgh et al., 1996; Santos et al., 2005; Sousa et al., 2006). However, excessive growth and grapes of an inferior quality could occur at low levels of water constraints (Deloire et al., 2004). An ideal irrigation strategy would be to maintain water constraint levels in grapevines, with slight yield losses being compensated for by improved grape and wine quality.
Measuring water constraints in grapevines could be useful to quantify the potential effects of irrigation strategies on yield as well as on grape quality. Previous studies on the effect of irrigation on grapevine water status in the coastal wine grape region were carried out in micro-sprinkler irrigated vineyards (Van Zyl \& Weber, 1981; Myburgh et al., 1996; Myburgh, 2005a). However, vineyards are increasingly being established under drip irrigation in this region. Since smaller soil volumes are wetted under drip irrigation, the effects of certain irrigation strategies on grapevine water status could be different compared to responses obtained with full surface irrigation, e.g. portable overhead sprinklers or micro-sprinklers.

Water potential has been widely used over decades as a measure of grapevine water constraints in response to different irrigation strategies (Hardie \& Considine, 1976; Van Zyl \& Weber, 1981; Van Zyl, 1987; Grimes \& Williams, 1990; Myburgh et al., 1996; Williams \& Araujo, 2002; Medrano et al., 2003; Myburgh, 2003; Pellegrino et al., 2004; Myburgh, 2005a; Myburgh \& Howell, 2006; Sousa et al., 2006). Water status in grapevines can be classified according to the predawn leaf water potential $\left(\Psi_{\mathrm{PD}}\right)$. It has been proposed that $\Psi_{\mathrm{PD}}$ values of - $0.2 \mathrm{MPa},-0.4 \mathrm{MPa}$, and -0.6 $\mathrm{MPa}$, respectively, could serve

\footnotetext{
The Fruit, Vine and Wine Institute of the Agricultural Research Council.
} 
as upper thresholds for "weak", "medium" and "strong" water constraints in Shiraz (Ojeda et al., 2002). A similar, but more general, classification was proposed by Deloire et al. (2004). It has also been suggested that grapevines experience no water constraints if $\Psi_{\mathrm{PD}}$ is higher than $-0.2 \mathrm{MPa}$, while $-0.3 \mathrm{MPa}$ to $-0.5 \mathrm{MPa}$ indicate moderate constraints (Carbonneau et al., 2004). Midday leaf water potential $\left(\Psi_{L}\right)$ could also be used to indicate the level of water constraints in grapevines (Winkel \& Rambal, 1993; Girona et al., 2006; Sousa et al., 2006). In this regard, $\Psi_{\mathrm{L}}$ values of approximately $-1 \mathrm{MPa},-1.2 \mathrm{MPa}$, -1.4 MPa and -1.6 MPa were proposed as lower threshold for no, mild, moderate and high water constraints respectively (Greenspan, 2005). Similarly, -0.8 MPa, -1.2 MPa and -1.5 MPa were considered to be $\Psi_{\mathrm{L}}$ thresholds for low, moderate and severe water constraints respectively (Girona et al., 2006 and references therein). Midday stem water potential $\left(\Psi_{S}\right)$ is also considered as a measure of grapevine water status (Choné et al., 2001; Patakas et al., 2005; Olivo et al., 2009).

The objective of this study was to determine the impact of different drip irrigation strategies on grapevine water status in a region where water resources are limited.

\section{MATERIALS AND METHODS \\ Experiment vineyard}

The field trial was carried out over four seasons, viz. 2003/04 until 2006/07, in a fifteen-year-old commercial Merlot/99 Richter vineyard near Wellington in the coastal wine grape region of the Western Cape, at $33^{\circ} 38^{\prime}$ latitude. The vineyard was on a southwest-facing slope at an altitude of $132 \mathrm{~m}$. The region has a Mediterranean climate, and based on the growing degree days (GDD) from September until March (Winkler, 1962), the specific locality is in a class V climatic region (Le Roux, 1974). The soil, which belongs to the Glenrosa form (Soil Classification Working Group, 1991), consisted of a 300 mm thick, sandy loam orthic A horizon on a sandy clay loam lithocutanic B horizon. The soil was deep delved to $1.0 \mathrm{~m}$ before planting. Grapevines were planted at a spacing of 3.0 $\mathrm{m} \times 1.0 \mathrm{~m}$ and trained onto a four-strand lengthened Perold trellis (Booysen et al., 1992). No vertical shoot positioning was carried out in order to allow the development of a sprawling canopy. The vineyard was previously irrigated by means of portable overhead sprinklers, but $2.3 \mathrm{~L} / \mathrm{h}$ UniRAM ${ }^{\circledR}$ drippers at $0.75 \mathrm{~m}$ spacing were used in the field trial.

\section{Experiment layout}

Five irrigation strategies were compared to a non-irrigated (i.e. rain fed or dry land) control (T1). Grapevines of two treatments (T2 and T4) received three irrigations, viz. (i) when the berries reached pea size ( $3^{\text {rd }}$ week in November), (ii) at véraison $\left(1^{\text {st }}\right.$ week in January) and (iii) post-harvest (March). Over the four seasons, approximately $32 \mathrm{~mm}$ of water was required per irrigation to restore the soil water content to field capacity in the $\mathrm{T} 2$ and T4 plots. A further two treatments (T3 and T5) received five irrigations, viz. (i) when the berries reached pea size, (ii) midway between pea size and véraison (mid-December), (iii) at véraison, (iv) midway between véraison and harvest (end January) and (v) post-harvest. Irrigations amounted to ca. 26 $\mathrm{mm}$ each, with five irrigations being applied during the first three seasons. In the 2006/07 season, the T3 and T5 grapevines were irrigated at a high frequency, i.e. twice a week from pea size berries until harvest. Following an initial irrigation of $c a$. $20 \mathrm{~mm}$ at pea size berries, $13 \mathrm{~mm}$ of water was applied per irrigation until the post-harvest period. In the case of the T2 and $\mathrm{T} 3$ plots, dripper lines were installed in the grapevine rows, whereas those of T4 and T5 were installed ca. $150 \mathrm{~mm}$ below the surface in the middle of the work rows.

A partial root zone drying (PRD) strategy was also included where irrigation was applied via subsurface dripper lines in the work rows (T6). Since the soil and roots had to re-settle where the subsurface irrigation lines were installed, the 2003/04 season was regarded as a pilot phase. In this particular season, irrigation was only applied every 14 days in alternating work rows of the T6 plots. Following an initial irrigation of $c a .20 \mathrm{~mm}$ at pea size berries, $14 \mathrm{~mm}$ of water was applied per irrigation until the postharvest period. In the 2004/05 season, irrigation was applied once a week in a set of alternating work rows to obtain a PRD effect. After approximately two to three weeks, irrigation was switched to the work rows that had been left to dry out. These cycles were repeated from pea size berries until harvest. In the case of the PRD strategy, two irrigation volumes were basically required. Small, frequent irrigations were required to maintain a relatively high soil water content in one set of alternating rows. When the irrigation was switched between the two sets of work rows, a relatively large initial irrigation was needed to restore the water content to field capacity in the set of work rows that had been left to dry out. In the 2004/05 season, the small weekly irrigations amounted to $c a .7 \mathrm{~mm}$, and the larger initial or "refill" ones to ca. $19 \mathrm{~mm}$. Since weekly irrigations were inadequate to maintain relatively wet soil conditions, a set of alternating PRD work rows was irrigated twice a week in the 2005/06 and 2006/07 seasons. In this case, $7 \mathrm{~mm}$ was applied twice a week, whereas the initial refill irrigations also amounted to $19 \mathrm{~mm}$. When T3 and T5 grapevines were irrigated at the same frequency as the PRD ones in the 2006/07 season, the latter strategy only required $35 \%$ less water compared to T3

\section{TABLE 1}

Irrigation volumes $\left(\mathrm{m}^{3}\right)$ applied where Merlot/99R was irrigated according to different irrigation strategies, including partial root zone drying (PRD), over four seasons near Wellington $\left(10 \mathrm{~m}^{3}=\right.$ $1 \mathrm{~mm}=0.01$ Megalitre per hectare).

\begin{tabular}{cccc}
\hline \multirow{2}{*}{ Season } & T2 \& T4 $^{(\mathbf{1})}$ & ${\text { T3 \& } \mathbf{T 5}^{(\mathbf{2})}}$ & T6 \\
\cline { 2 - 4 } & $\begin{array}{c}\text { Three } \\
\text { irrigations }\end{array}$ & $\begin{array}{c}\text { Five } \\
\text { irrigations }\end{array}$ & PRD \\
\hline $2003 / 04$ & 922 & 1194 & $1250^{(3)}$ \\
$2004 / 05$ & 1033 & 1298 & 1801 \\
$2005 / 06$ & 890 & 1334 & 2490 \\
$2006 / 07$ & 961 & $3667^{(4)}$ & 2392 \\
\hline
\end{tabular}

(1) Irrigations at pea size, véraison and post-harvest.

(2) Irrigations at pea size, mid-December, véraison, end January and post harvest.

(3) In 2003/04, the T6 grapevines received only low frequency irrigation in alternating work rows.

(4) In 2006/07, the T3 and T5 grapevines were irrigated at the same frequency as the PRD ones. 
and T5. Due to the larger refill irrigations, it was not possible to save $50 \%$ on the irrigation water compared to T3 and T5, although only half of the work rows were irrigated at a time. All treatments were replicated four times in a randomised block design. Experimental plots comprised two rows of six grapevines each, with two buffer grapevines at each end and a buffer row on each side. Each experimental plot covered 144 $\mathrm{m}^{2}$. Irrigation volumes were monitored by means of flow meters and converted to cubic meters per hectare (Table 1).

\section{Soil water}

Soil water content was measured over $300 \mathrm{~mm}$ increments to a depth of $900 \mathrm{~mm}$ using the neutron scattering technique. Access tubes were installed in the grapevine row in all plots. In order to follow partial root zone drying, and to compare it to the control, access tubes were installed in the middle of all the work rows in the T1, T4, T5 and T6 plots. A field calibration was carried out to convert neutron counts to volumetric soil water content. Soil water content was measured weekly, as well as before and after irrigations. Soil water retention was determined by the ARC Institute for Soil, Climate and Water in Pretoria using the pressure pot technique (Klute, 1986). For this purpose, disturbed soil samples were collected over $300 \mathrm{~mm}$ increments to a depth of $900 \mathrm{~mm}$. Total plant available water (PAW) was calculated as the difference in soil water content between matric potentials of $-0.05 \mathrm{MPa}$ (field capacity) and -1.5 MPa (permanent wilting point). Water meters were used to monitor the irrigation volumes applied to each treatment. Since the neutron probe access tubes in the work rows complicated the cultivation of a winter cover crop, and tillage damaged the subsurface drip lines in the first season, the work rows were mulched using wheat straw in January 2005. At that stage, samples were collected from $6 \mathrm{~m}^{2}$ sub-plots in six treatment plots and weighed to calculate the straw mass per hectare. Winter-growing weeds on the under-vine banks were controlled chemically in August.

\section{Grapevine water potential}

To quantify grapevine water status, water potentials were determined in mature leaves on primary shoots by means of the pressure chamber technique (Scholander et al., 1965). Midday $\Psi_{\mathrm{L}}$ was measured in leaves fully exposed to the sun, whereas leaves were covered in aluminium bags at least one hour before measuring $\Psi_{\mathrm{S}}$. Water potentials were determined in all treatments in one grapevine per plot shortly before the grapes were harvested. In the 2005/06 and 2006/07 seasons, $\Psi_{\mathrm{L}}$ and $\Psi_{\mathrm{S}}$ were also measured at véraison. On 11 January and 8 February
2006 , the hourly variation in leaf water potential was measured from 04:00 until 03:00 the next day. In addition to the hourly data, $\Psi_{L}$ was measured at 30-minute intervals from 08:00 until 20:00 on these days. A set of leaf water potential measurements was completed within approximately ten minutes by five teams of two persons each. All pressure chambers were custom built and calibrated against a precision pressure gauge. Total diurnal leaf water potential $\left(\Psi_{\mathrm{Tot}}\right)$ was calculated using the trapezoidal rule (Larson et al., 1994) as described by Myburgh and Howell (2006). The diurnal leaf water potential variation was only measured in three replications of each treatment.

\section{Atmospheric conditions}

Air temperature, relative humidity, incoming solar radiation and wind speed were recorded hourly at the experimental vineyard by means of an automatic weather station (MC Systems, Cape Town). Rainfall was recorded weekly at the experimental vineyard using a standard rain gauge. Long-term mean monthly rainfall data for Wellington were obtained from the ARC Institute for Soil, Climate and Water in Pretoria.

\section{Statistical analysis}

The data were subjected to an analysis of variance. Least significant difference (LSD) values were calculated to facilitate comparison between treatment means. Means that differed at $p \leq$ 0.05 were considered to be significantly different. Statgraphics ${ }^{\circledR}$ was used to fit linear regression models.

\section{RESULTS AND DISCUSSION}

\section{Surface mulch}

Due to its initial thickness of $6.0 \pm 0.7 \mathrm{t} / \mathrm{ha}$, as well as annual re-growth of the wheat seeds during winter, the straw mulch visually provided efficient weed control in the work rows until the end of the field trial. An 8 t/ha wheat straw mulch significantly suppressed high evaporation losses from the soil surface only up to three days after an irrigation or rainfall (Myburgh, 1998). A straw mulch of 7.5 t/ha reduced the irrigation requirement of grapevines in the Breede River Valley that were irrigated weekly by approximately $11 \%$ compared to a bare soil surface (J.C. Fourie, personal communication, 2010). Furthermore, evaporation losses from the soil surface will also be reduced by the limited wetted area in drip irrigated vineyards. This suggested that the straw mulch may have reduced the evapotranspiration (ET) of the non-irrigated and low frequency irrigation strategies substantially. However, where the PRD strategy as well as high frequency irrigations were applied in 2006/07 (T3 and T5), the mulch could also have

TABLE 2

Mean monthly and total rainfall (mm) measured over four seasons near Wellington compared to the long-term means (LTM).

\begin{tabular}{ccccccccc}
\hline Season & Sept & Oct & Nov & Dec & Jan & Feb & Mar & Total \\
\hline $2003 / 04$ & 63 & 21 & 0 & 13 & 17 & 0 & 10 & 125 \\
$2004 / 05$ & 33 & 105 & 11 & 4 & 68 & 4 & 6 & 231 \\
$2005 / 06$ & 47 & 31 & 45 & 0 & 0 & 15 & 11 & 149 \\
$2006 / 07$ & 46 & 36 & 52 & 21 & 0 & 23 & 34 & 212 \\
LTM & 47 & 26 & 23 & 20 & 15 & 13 & 26 \\
\hline
\end{tabular}



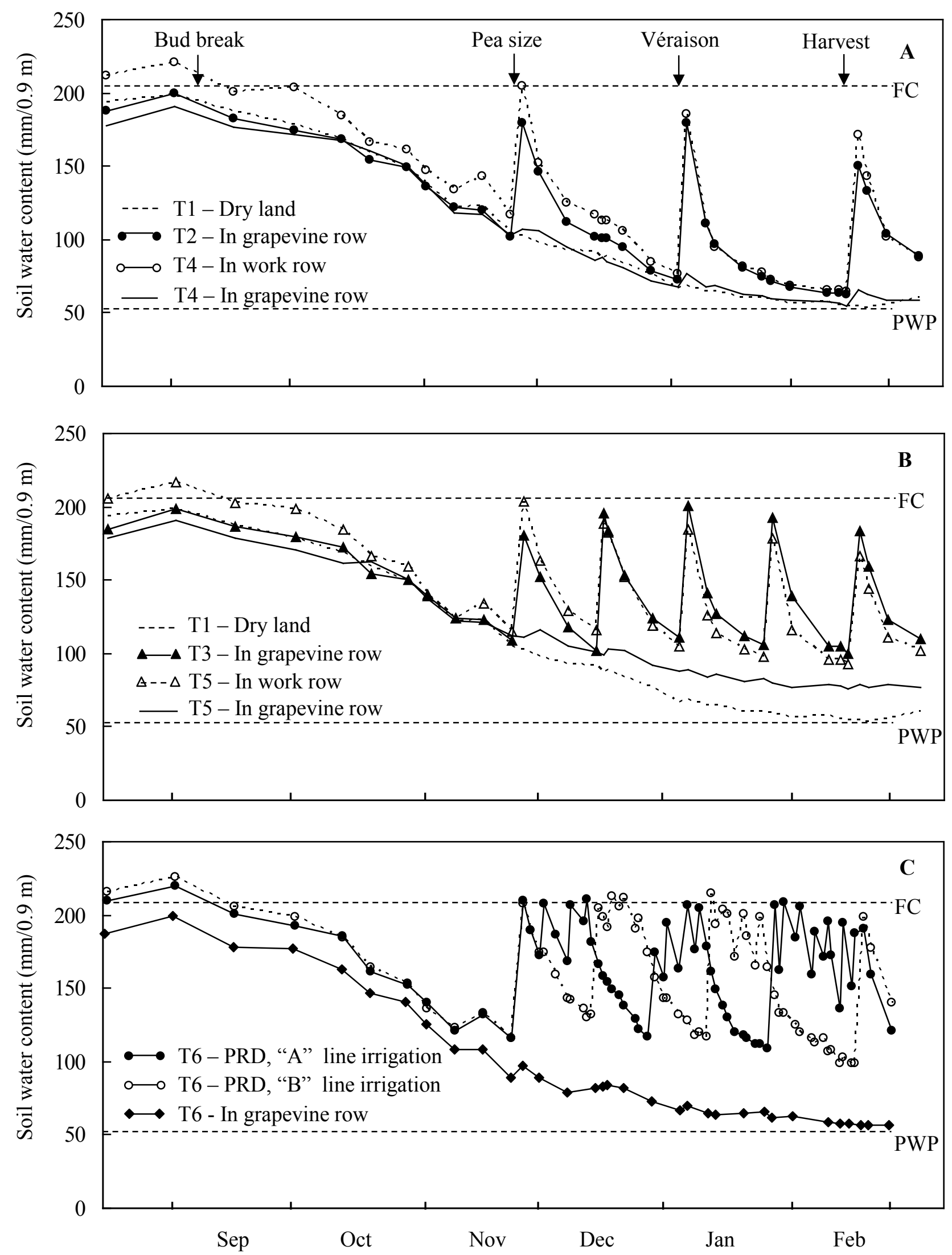

FIGURE 1

Effect of non-irrigated conditions, low frequency drip irrigations and position of irrigation lines (A and B), as well as (C) partial root zone drying $(\mathrm{PRD})$ on the variation in soil water content measured during the 2005/06 season. $(\mathrm{FC}=$ field capacity and $\mathrm{PWP}=$ permanent wilting point). 
reduced ET compared to a bare soil surface.

\section{Soil water content}

Although rainfall is expected to show considerable variability in the Western Cape (Dent et al., 1988), total monthly rainfall followed the long-term mean trend over the four seasons (Table 2). The only exceptions were no rainfall in November 2003 and relatively high rainfall in October 2004 and January 2005. Plant available water amounted to $c a$. $160 \mathrm{~mm}$ over the $0.9 \mathrm{~m}$ root depth in this particular soil. In the case of the nonirrigated treatment (T1), soil water was depleted at a slow rate during berry ripening (Fig. 1A). At harvest in February, the soil water content was nearly depleted to permanent wilting point. The high level of PAW depletion in the non-irrigated soil occurred during all four seasons (data not shown). Similar high levels of PAW depletion were reported for non-irrigated vineyards in the Stellenbosch area (Van Zyl \& Weber, 1981; Conradie et al., 2002; Laker, 2004). Earlier results showed that the ET of non-irrigated vineyards in the Stellenbosch area was only $c a$. $0.6 \mathrm{~mm} /$ day when the soil water content was near permanent wilting point during berry ripening (Laker, 2004; Myburgh, 2005a). Due to the low soil water content and the straw mulch, evaporation losses from the soil surface would have been extremely low at that stage (Myburgh, 1998). Therefore, it can be assumed that ET consisted primarily of the transpiration component, which probably caused the low soil water depletion rate during berry ripening.
When the first irrigations were applied at pea size berries in November, approximately $60 \%$ of the PAW had been depleted (Fig. 1A). A rapid decline in soil water content occurred during the ten to 14 days following the irrigations. Soil water was depleted at a considerably lower rate after the initial stage of rapid decline. Where only two irrigations were applied before harvest (T2 and T4), PAW had been depleted to $c a$. $87 \%$ before the second irrigation was applied at véraison early in January (Fig. 1A). At harvest, PAW depletion in the grapevine rows (T2) and work rows (T4) was approximately 95\%, which was only slightly wetter compared to the depletion level in the nonirrigated situation (T1). The high level of PAW depletion in spite of the two irrigations applied before harvest agreed with previous findings (Van Zyl \& Weber, 1981; Myburgh, 2005a). Where three irrigations were applied in the work rows (T4), soil water content in the non-irrigated grapevine rows was depleted to the same level as in the non-irrigated treatment at harvest (Fig. 1A). After irrigations were applied in the middle of the work rows, water content increased only slightly in the grapevine rows. This indicated that minimal lateral water flow had occurred from the middle of the work rows into the grapevine rows. Where four irrigations were applied before harvest (T3 and T5), ca. two thirds of the PAW was depleted between irrigations. The soil water content mostly remained within the "rapid depletion range" until harvest (Fig. 1B). Where five irrigations were applied in the work rows (T5), less soil water depletion occurred in the grapevine rows compared

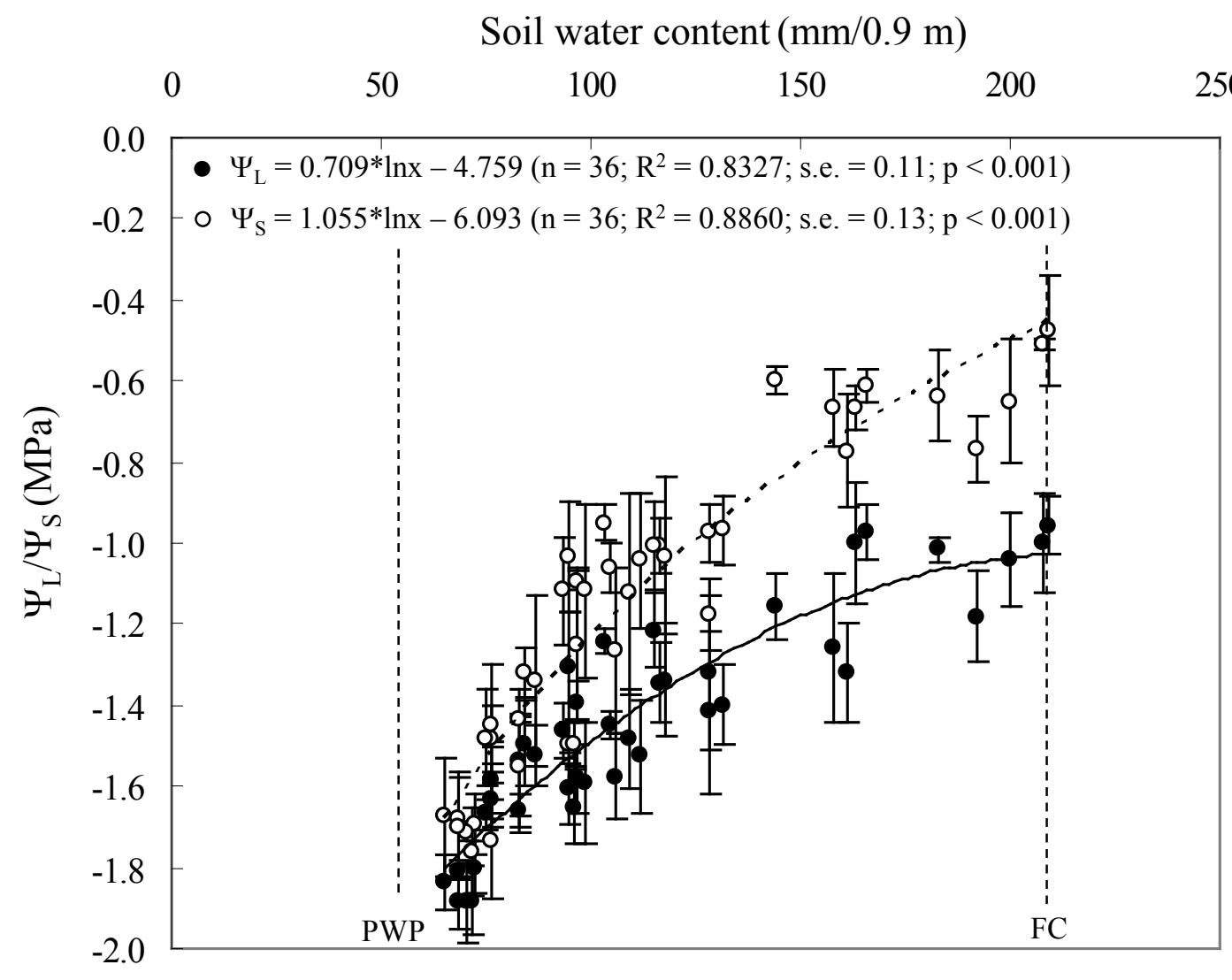

FIGURE 2

Relationship between midday leaf $\left(\Psi_{\mathrm{L}}\right)$ and stem $\left(\Psi_{\mathrm{S}}\right)$ water potential in Merlot/99R grapevines and soil water content as measured over four seasons near Wellington. Vertical bars indicate standard deviation $(n=4)$. 
to the situation under non-irrigated conditions. This indicated that substantially more lateral water flow occurred from the middle of the work rows into the grapevine rows compared to only two irrigations before harvest (T4). When the grapevines were irrigated at a high frequency in the grapevine rows (T3) and work rows (T5) during the 2006/07 season, PAW was depleted to $c a$. $30 \%$ between irrigations from November until harvest (data not shown).

During the 2003/04 season, when the PRD concept was applied at a low frequency in alternating work rows, soil water depletion was comparable to the treatments where only two irrigations were applied before harvest (data not shown). Applying $7 \mathrm{~mm}$ of irrigation once a week in the 2004/05 season resulted in a gradual decline in soil water content in the alternating work rows that were irrigated (data not shown). In the following two seasons, PAW depletion was generally less than $c a$. $30 \%$ when irrigations were applied twice a week in the alternating work rows (Fig. 1C). In work rows that were left to dry out to obtain the PRD effect, PAW depletion levels were comparable to those where four irrigations were applied before harvest (T5). Soil water content in the grapevine rows of the PRD treatment was depleted to levels that were comparable to the non-irrigated treatment (Fig. 1C). This result shows that the PRD grapevines obtained most of their water from the irrigation applied in the work rows. Since smaller volumes of water were applied with the PRD strategy compared to the lower irrigation frequencies, minimal lateral flow probably occurred from the work rows into the grapevine rows.

It should be noted that the soil water content in the grapevine rows of T2, T3 and T6 tended to be lower than in the work rows of the T4, T5 and T6 plots from bud break until the first irrigations were applied (Fig. 1). This effect was also observed in the case of the non-irrigated plots, where soil water content was measured in the grapevine rows as well as in the work rows (data not shown). This trend suggests that water infiltration was less efficient in the grapevine rows than in the work rows, probably due to the absence of the surface mulch. Furthermore, chemical weed control rendered the grapevine rows visually almost free from any form of plant material that could have enhanced water infiltration, particularly during winter. It was previously reported that soil water content did not vary significantly between grapevine rows and work rows when the soil was left bare (Pellegrino et al., 2004).

\section{Grapevine water potential relationships}

Both $\Psi_{\mathrm{L}}$ and $\Psi_{\mathrm{S}}$ decreased non-linearly as the soil water content diminished from field capacity to almost permanent wilting

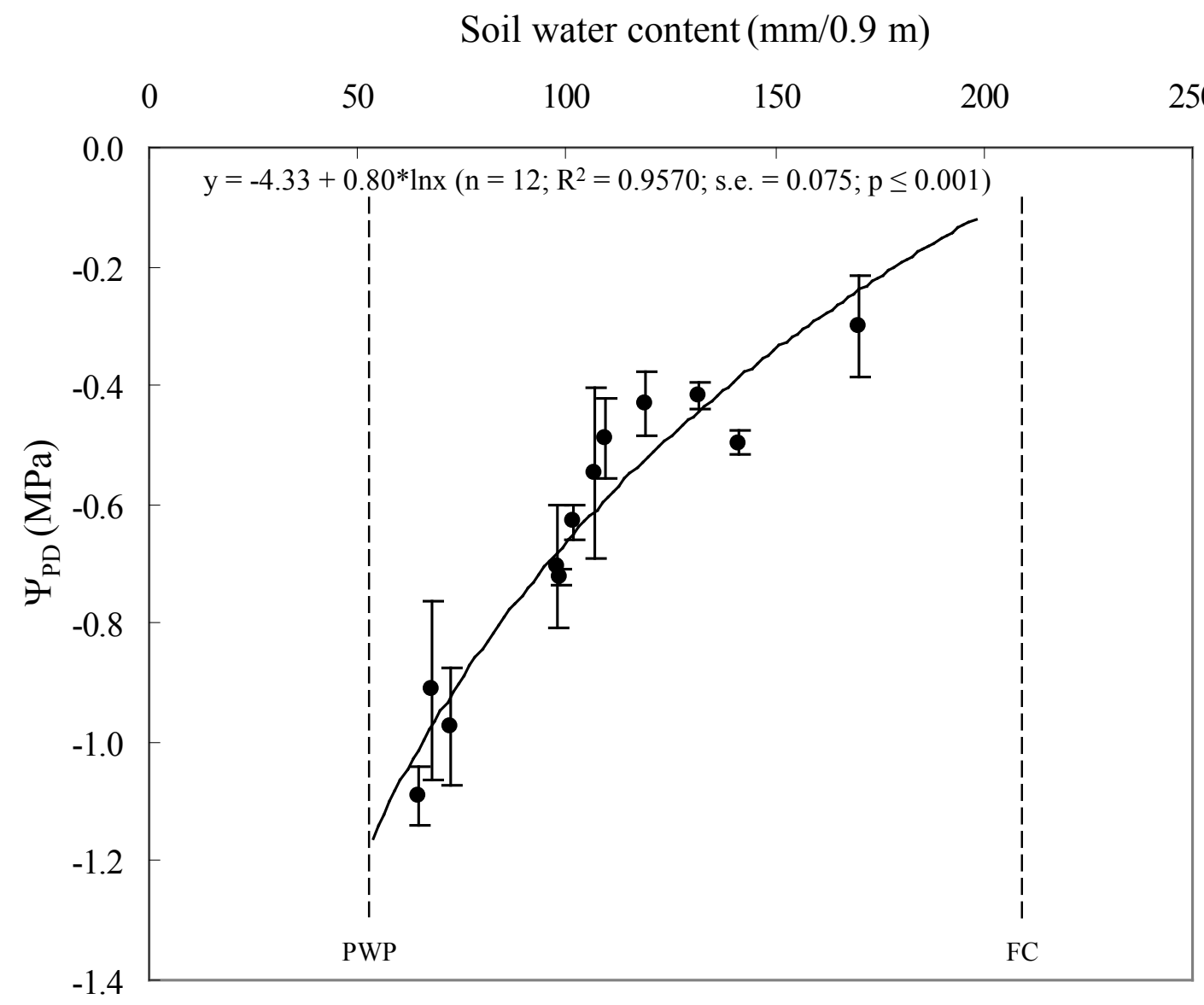

FIGURE 3

Relationship between predawn leaf water potential $\left(\Psi_{\mathrm{PD}}\right)$ in Merlot/99R grapevines and soil water content as measured in the 2005/06 season near Wellington. Dashed vertical lines indicate permanent wilting point (PWP) and field capacity (FC). Vertical bars indicate standard deviation $(\mathrm{n}=3)$. 
point (Fig. 2). A similar non-linear relationship between $\Psi_{\mathrm{PD}}$ and soil water content was reported for Shiraz (Pellegrino et al., 2004). This is contradictory to the linear relationships between midday grapevine water potential and soil water content established in previous studies (Williams \& Araujo, 2002; Sousa et al., 2006). Using the equations reported by Williams and Araujo (2002) to estimate $\Psi_{\mathrm{L}}$ from volumetric soil water content produced unrealistic values. Since midday $\Psi_{L}$ only varied between $-1.17 \mathrm{MPa}$ and $-1.46 \mathrm{MPa}$ in the study carried out by Sousa et al. (2006), it is possible that the relationship could be interpreted as being linear in such a limited $\Psi_{L}$ range. Under the given conditions, variation in soil water content explained $83 \%$ and $89 \%$ of the variation in $\Psi_{L}$ and $\Psi_{S}$ respectively. Other factors, such as partial stomatal closure caused by changes in atmospheric conditions, probably also contributed to the variation in grapevine water potential. There was an exceptionally high correlation between $\Psi_{\mathrm{S}}$ and $\Psi_{\mathrm{L}}\left(\mathrm{R}^{2}=\right.$ 0.9063 ; standard error $=0.08 ; p<0.001 ; \mathrm{n}=40)$, which was in agreement with earlier findings (Williams \& Araujo, 2002). The difference between $\Psi_{\mathrm{L}}$ and $\Psi_{\mathrm{S}}$ became smaller as the soil water content approached permanent wilting point (Fig. 2). This trend indicated that atmospheric conditions had a more pronounced reducing effect on $\Psi_{\mathrm{L}}$ in the higher soil water content range than in drier soil conditions.

Predawn leaf water potential also decreased non-linearly from field capacity to permanent wilting point (Fig. 3). However, the relationship between $\Psi_{\mathrm{PD}}$ and the soil water content was almost linear compared to that between midday $\Psi_{L}$ and $\Psi_{S}$ (Fig. 2). Under the given conditions, both midday $\Psi_{\mathrm{L}}$ and $\Psi_{\mathrm{S}}$ correlated well with $\Psi_{\mathrm{PD}}$, but decreased non-linearly as the latter decreased (Fig. 4). The relationships seemed to be almost linear when $\Psi_{\mathrm{PD}}$ was higher than $c a$. $-0.8 \mathrm{MPa}$. Williams and Araujo (2002) also showed that $\Psi_{L}$ and $\Psi_{S}$ were linearly related to $\Psi_{\mathrm{PD}}$ when the latter was higher than $-0.8 \mathrm{MPa}$. Total diurnal leaf water potential correlated exceptionally well with $\Psi_{\text {PD }}$ (Fig. 5). Based on the $\Psi_{\mathrm{PD}}$ thresholds for different water constraints classifications proposed previously (Ojeda et al., 2002; Deloire et al., 2004), the equations in Figures 4 and 5 were used to estimate corresponding water constraint, or water deficit, thresholds for $\Psi_{\mathrm{L}}, \Psi_{\mathrm{S}}$ and $\Psi_{\text {Tot }}$ in Merlot grapevines under the given conditions (Table 3). The estimated $\Psi_{L}$ thresholds tended to be lower compared to values proposed previously (Greenspan, 2005; Girona et al., 2006). However, it must be noted that the $\Psi_{\mathrm{L}}, \Psi_{\mathrm{S}}$ and $\Psi_{\text {Tot }}$ thresholds estimated in this study would probably not be universally applicable, but merely served as a means to interpret the results of the present study in relation to previous water potential classifications.

\section{Diurnal leaf water potential}

When the diurnal evolution of leaf water potential was measured on 11 January, i.e. at véraison, light clouds that were blown in from a south-easterly direction from 10:00 to 12:00 reduced incoming solar radiation compared to the uninterrupted sunshine on 8 February, i.e. near harvest (Fig. 6A). In the early

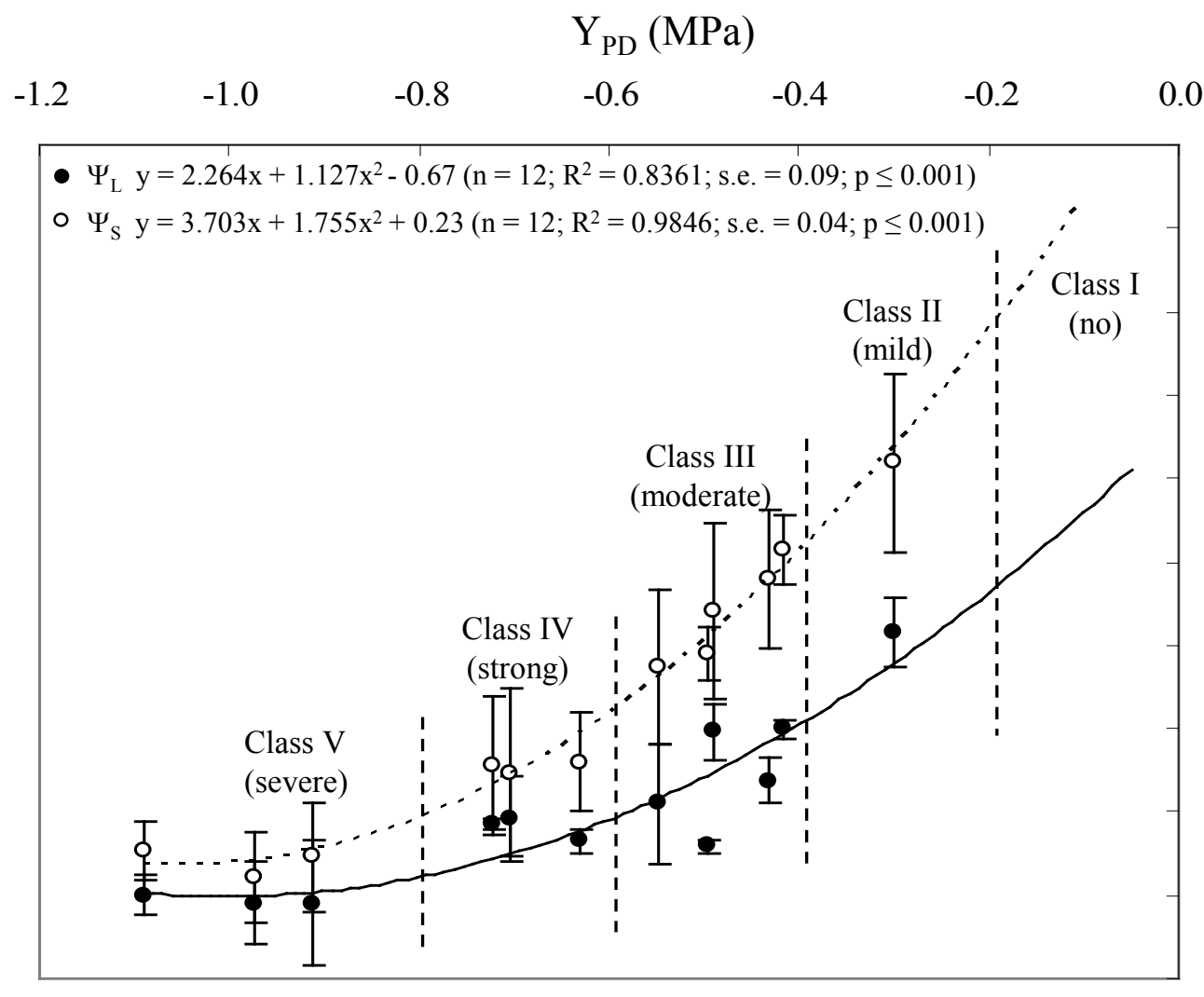

0.0

0.0

$-0.4$

$-0.6$

$-0.8$

$-1.0$

$-1.4$

$-1.6$

$-1.8$

$-2.0$

FIGURE 4

Relationship between midday leaf $\left(\Psi_{\mathrm{L}}\right)$ and stem $\left(\Psi_{\mathrm{S}}\right)$ water potential and predawn leaf water potential $\left(\Psi_{\mathrm{PD}}\right)$ in Merlot/99R grapevines as measured during the 2005/06 season near Wellington. Vertical bars indicate standard deviation $(n=3)$. 
afternoon on 11 January, smoke generated by a veld fire to the northwest of the experimental vineyard had a similar effect on solar radiation. The reduction in solar radiation probably contributed to lower air temperatures on 11 January compared to 8 February, when temperatures exceeded $30^{\circ} \mathrm{C}$ from $c a$. 11:00 to 18:00. As a result, the vapour pressure deficit (VPD) also tended to be lower on 11 January than on the normal sunshine day (Fig. 6B). On both days, the higher wind speeds during the afternoon were probably caused by the typical sea breeze effect occurring in the coastal region of the Western Cape (Bonnardot et al., 2001). The slightly higher wind speeds during the afternoon of 11 January could also have contributed to the lower air temperatures compared to 8 February.

The level of soil water depletion was reflected clearly in grapevine water status when diurnal $\Psi_{\mathrm{L}}$ evolution was measured before irrigations were applied at véraison (Fig. 7). The low $\Psi_{L}$ at predawn indicated that the water status of the non-irrigated grapevines (T1) could not recover during the preceding

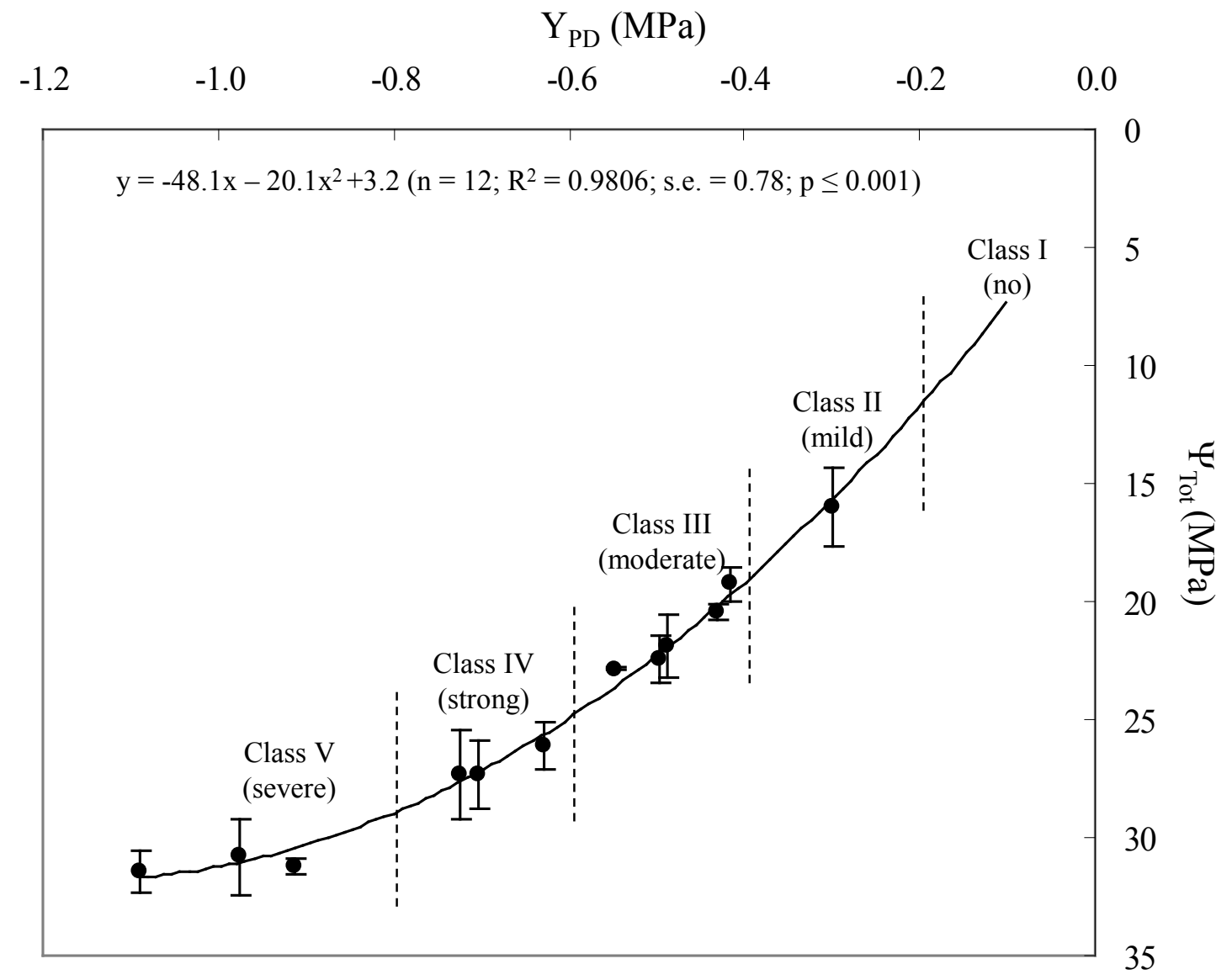

FIGURE 5

Relationship between total diurnal leaf water potential $\left(\Psi_{\mathrm{Tot}}\right)$ and predawn leaf water potential $\left(\Psi_{\mathrm{PD}}\right)$ in Merlot/99R grapevines as measured in the 2005/06 season near Wellington. Vertical bars indicate standard deviation $(n=3)$.

TABLE 3

Water stress thresholds for leaf $\left(\Psi_{\mathrm{L}}\right)$, stem $\left(\Psi_{\mathrm{S}}\right)$ and total diurnal $\left(\Psi_{\mathrm{Tot}}\right)$ water potential in Merlot/99R near Wellington as estimated from the predawn leaf water potential $\left(\Psi_{\mathrm{PD}}\right)$ water stress classifications as proposed by Ojeda et al. (2002) and Deloire et al. (2004).

\begin{tabular}{|c|c|c|c|c|c|}
\hline \multirow{2}{*}{ Class } & \multirow{2}{*}{$\begin{array}{l}\text { Water } \\
\text { stress }\end{array}$} & \multicolumn{4}{|c|}{ Water potential thresholds } \\
\hline & & (MPa) & (MPa) & (MPa) & $\left(\mathrm{MPa}^{2}\right)$ \\
\hline I & None & $\Psi_{\mathrm{PD}} \geq-0.2$ & $\Psi_{\mathrm{L}} \geq-1.1$ & $\Psi_{\mathrm{S}} \geq-0.4$ & $\Psi_{\mathrm{Tot}} \leq 12$ \\
\hline II & Mild & $-0.2>\Psi_{\mathrm{PD}} \geq-0.4$ & $-1.1>\Psi_{L} \geq-1.4$ & $-0.4>\Psi_{\mathrm{S}} \geq-1.0$ & $12<\Psi_{\mathrm{Tot}} \leq 19$ \\
\hline III & Moderate & $-0.4>\Psi_{\mathrm{PD}} \geq-0.6$ & $-1.4>\Psi_{L} \geq-1.6$ & $-1.0>\Psi_{S} \geq-1.4$ & $19<\Psi_{\mathrm{Tot}} \leq 25$ \\
\hline IV & Strong & $-0.6>\Psi_{\mathrm{PD}} \geq-0.8$ & $-1.6>\Psi_{L} \geq-1.8$ & $-1.4>\Psi_{\mathrm{S}} \geq-1.6$ & $25<\Psi_{\mathrm{Tot}} \leq 29$ \\
\hline $\mathrm{V}$ & Severe & $\Psi_{\mathrm{PD}}<-0.8$ & $\Psi_{L}<-1.8$ & $\Psi_{\mathrm{S}}<-1.6$ & $\Psi_{\mathrm{Tot}}>29$ \\
\hline
\end{tabular}



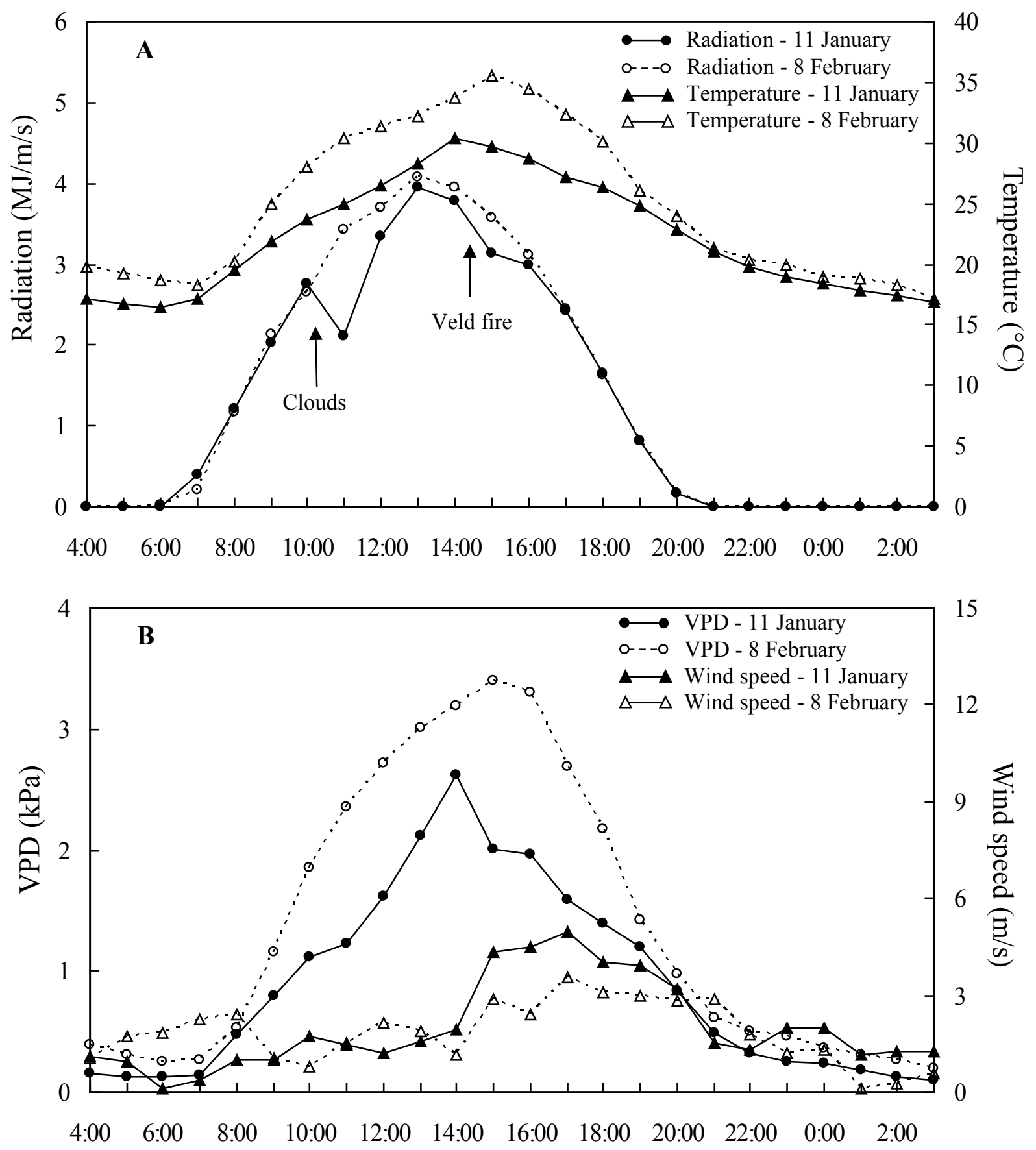

Time

FIGURE 6

Diurnal variation in (A) incoming solar radiation and air temperature, as well as (B) vapour pressure deficit (VPD) and wind speed, as measured at véraison (11 January) and before harvest (8 February) during the 2005/06 season near Wellington. Arrows indicate the occurrence of clouds and a veld fire on 11 January.

night and that they experienced strong water constraints (Table 3). However, $\Psi_{\mathrm{PD}}$ was considerably lower in comparison to approximately $-0.28 \mathrm{MPa}$ in non-irrigated Chenin blanc grapevines during berry ripening in the Stellenbosch area (Van Zyl \& Weber, 1981). The lower $\Psi_{\mathrm{PD}}$ near Wellington was probably caused by warmer, less humid atmospheric conditions than in Stellenbosch. Long-term mean February temperatures for Stellenbosch and Wellington are $21.5^{\circ} \mathrm{C}$ and $24.3^{\circ} \mathrm{C}$ respectively (Myburgh, 2005b). Following the predawn period, declined rapidly until 09:00. At that stage, $\Psi_{L}$ was less than $-1.6 \mathrm{MPa}$, which indicates that the grapevines still experienced strong water constraints. For the next seven hours, $\Psi_{\mathrm{L}}$ fluctuated between $-1.55 \mathrm{MPa}$ and $-1.75 \mathrm{MPa}$, indicating that strong water constraint levels continued during the warmest part of the day. Interruptions in incoming solar radiation caused by clouds and the veld fire probably contributed to the fluctuations in 


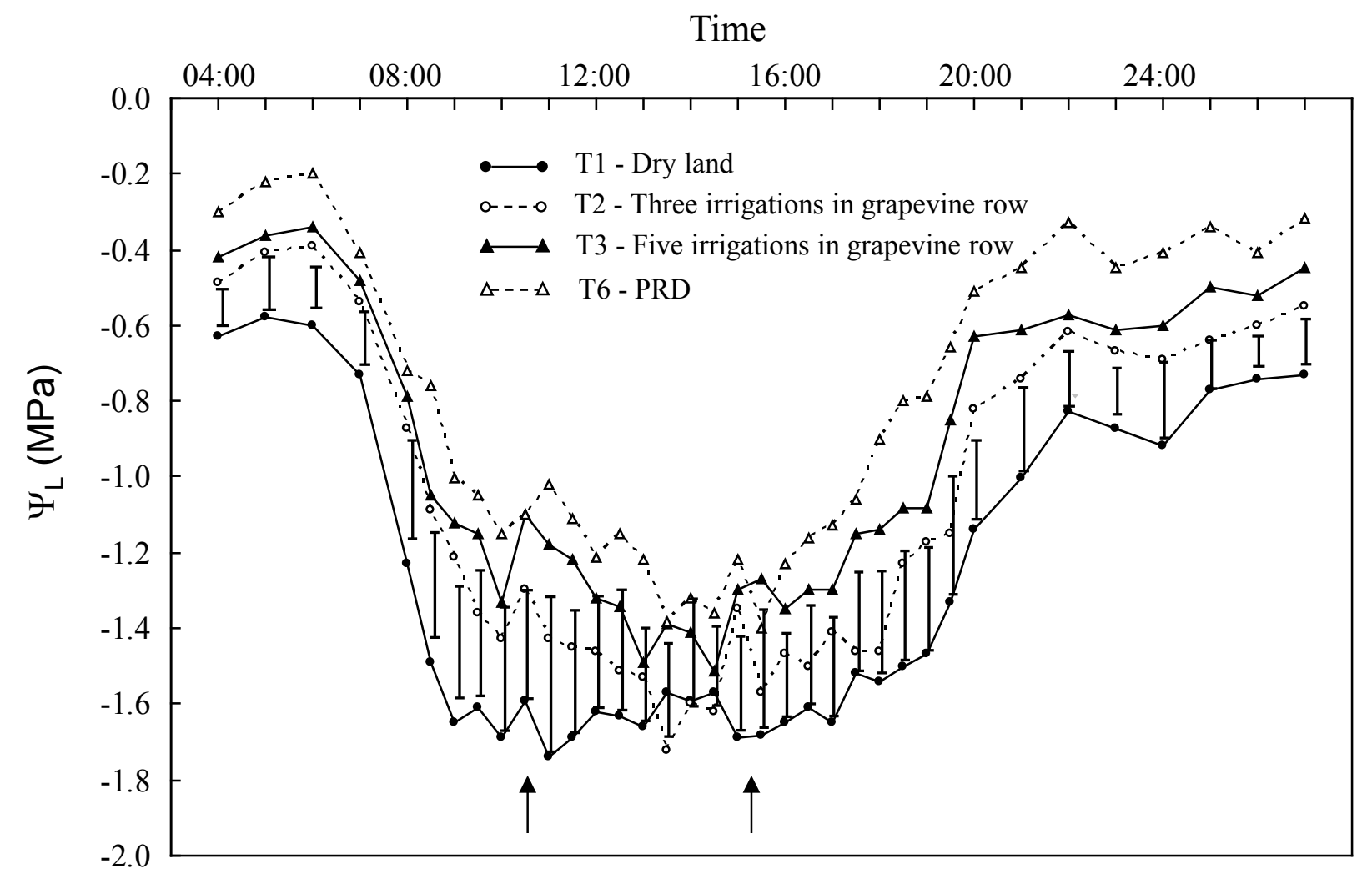

FIGURE 7

Effect of non-irrigated conditions, low frequency irrigation and partial root zone drying (PRD) on leaf water potential ( $\left.\Psi_{L}\right)$ in Merlot/99R as measured on 11 January 2006 near Wellington. Arrows indicate the occurrence of clouds in the morning and a veld fire in the afternoon. Vertical bars indicate the lowest significant difference $(p \leq 0.05)$.

$\Psi_{\mathrm{L}}$ and prevented the development of more water constraints during daytime. A steep $\Psi_{\mathrm{L}}$ increase from 17:00 until 22:00 was followed by a more subdued increase until $\Psi_{\mathrm{L}}$ reached the same level during the predawn period as on the previous day.

Grapevines that were irrigated once in the grapevine row before véraison (T2) experienced moderate predawn water constraints (Table 3), which implies that their water status could recover partly during the night. From predawn until 09:00, and from 20:00 onwards, T2 grapevines were subjected to less water constraints than the non-irrigated ones (Fig. 8). Although $\Psi_{\mathrm{L}}$ also fluctuated as a result of instability in the atmospheric conditions, water constraints in the $\mathrm{T} 2$ grapevines was primarily moderate during the warmest part of the day. Grapevines that had already received three irrigations in the grapevine row (T3) also experienced moderate predawn water constraints, but their $\Psi_{L}$ was higher than that of the non-irrigated grapevines for the major part of the diurnal cycle. During the warmest part of the day, T3 grapevines only experienced mild to moderate water constraints (Table 3). Grapevines that were irrigated according to the PRD strategy (T6) were only subjected to mild levels of water constraints throughout the diurnal cycle. This indicates that $\Psi_{\mathrm{L}}$ in the PRD grapevines responded to the higher soil water content in the alternating work rows where irrigation was applied two times per week. There was almost no difference in the diurnal water status between grapevines that had been irrigated once (T2 and T4) and those that received two irrigations before véraison (T3 and T5) (Fig. 8). In the case of low frequency irrigation, it was clear that the subsurface dripper lines in the work row (T4 and T5) had no effect on grapevine water status compared to those where irrigation was applied in the grapevine row (T2 and T3).

A week before the grapes were harvested, the uninterrupted incoming solar radiation, which caused warmer and drier atmospheric conditions as well as the lower wind speeds on 8 February (Fig. 6A), probably caused the generally lower grapevine $\Psi_{\mathrm{L}}$ values compared to 11 January (Fig. 9). The lower soil water content on 8 February compared to véraison (Fig. 1) could also have lowered $\Psi_{\mathrm{L}}$ in the non-irrigated grapevines (T1) and in those that received only two irrigations before harvest (T2 and T4). With the exception of the PRD strategy, predawn $\Psi_{L}$ in grapevines of most treatments indicated that they experienced severe water constraints on 11 January (Fig. 9). Hence, water constraints in non-irrigated, as well as low frequency irrigated grapevines, could not recover during the preceding night under the prevailing soil and atmospheric conditions. The fact that $\Psi_{L}$ in these grapevines was less than -1.6 $\mathrm{MPa}$ indicates that they were experiencing strong to severe water constraints during the warmest part of the day. The fluctuating $\Psi_{\mathrm{L}}$ values during the day suggest that the grapevines were able to avoid further water constraint increases by mechanisms such as partial stomatal closure and/or osmotic adjustment. A similar fluctuating or "oscillating" trend was observed where $\Psi_{L}$ in Sultanina grapevines was measured at 15-min intervals under warm and dry, but stable, atmospheric 
conditions in the Lower Orange River region (Myburgh, 2007). As expected, $\Psi_{\mathrm{L}}$ in grapevines that had received four irrigations before harvest was higher than in the non-irrigated ones and in those that had received only two irrigations (Fig. 9). The PRD grapevines experienced substantially less water constraints compared to the other treatments. In contrast to the situation at véraison, there were most of the time differences in $\Psi_{L}$ between grapevines that received two irrigations (T2 and T4) and those that received four irrigations before harvest, i.e. T3 and T5 (Fig. 10). The position of the dripper lines also had no effect on diurnal grapevine water status prior to harvest.

At véraison, $\Psi_{\text {Tot }}$ in the non-irrigated grapevines was higher than in the other irrigation strategies (Table 4). Variations in atmospheric conditions between the measuring days also reflected in $\Psi_{\text {Tot }}$ being lower on 11 January than on 8 February. Prior to harvest, $\Psi_{\text {Tot }}$ in the non-irrigated grapevines was appreciably higher compared to the $c a .17 \mathrm{MPa}^{2}$ in nonirrigated Sauvignon blanc near Stellenbosch during February (Laker, 2004). Since PAW was comparably low at both localities, the lower water constraints in the Sauvignon blanc grapevines was probably caused by more moderate atmospheric conditions when $\Psi_{\text {Tot }}$ was determined near Stellenbosch, i.e. air temperature and vapour pressure deficit (VPD) less than $30^{\circ} \mathrm{C}$ and $2 \mathrm{kPa}$ respectively (Laker, 2004). Two irrigations applied before harvest (T2 and T4) resulted in higher $\Psi_{\mathrm{Tot}}$ in grapevines than in those that received four irrigations in the grapevine rows (T3). Although $\Psi_{\text {Tot }}$ in the PRD grapevines was substantially lower compared to those of the other treatments, it was still higher than the ca. $11 \mathrm{MPa}^{2}$ determined between 04:00 and 24:00 in micro-sprinkler irrigated table grapes that experienced no to mild water constraints (Myburgh \& Howell, 2006). In contrast to the situation at véraison, $\Psi_{\text {Tot }}$ in the grapevines that received two irrigations (T2 and $\mathrm{T} 4$ ) was similar to that in the non-irrigated vines before harvest, irrespective of the position of the dripper lines (Table 4). Higher soil water contents resulting from four irrigations before harvest (T3 and T5) caused lower $\Psi_{\text {Tot }}$ in grapevines than those that received two irrigations. Likewise, $\Psi_{\text {Tot }}$ in grapevines irrigated according to the PRD strategy was substantially lower compared to those of the other treatments.

\section{Midday leaf water potential Around véraison}

Given the strong correlation between midday $\Psi_{\mathrm{L}}$ and $\Psi_{\mathrm{S}}$, variation in grapevine water constraints between seasons will only be discussed according to $\Psi_{\mathrm{S}}$ (Table 5). During the $2005 / 06$ and $2006 / 07$ seasons, midday $\Psi_{\mathrm{S}}$ indicated that the non-irrigated grapevines (T1) were already experiencing strong to moderate water constraints at véraison. Since grapevines that received only a single irrigation (T2 and T4) were also experiencing strong to moderate water constraints, the irrigation did not improve grapevine water status at véraison compared to non-irrigated grapevines. However, mild water constraints indicated that the two irrigations applied before véraison (T3 and T5) improved the grapevine water status compared to the non-irrigated grapevines during both seasons. Grapevines

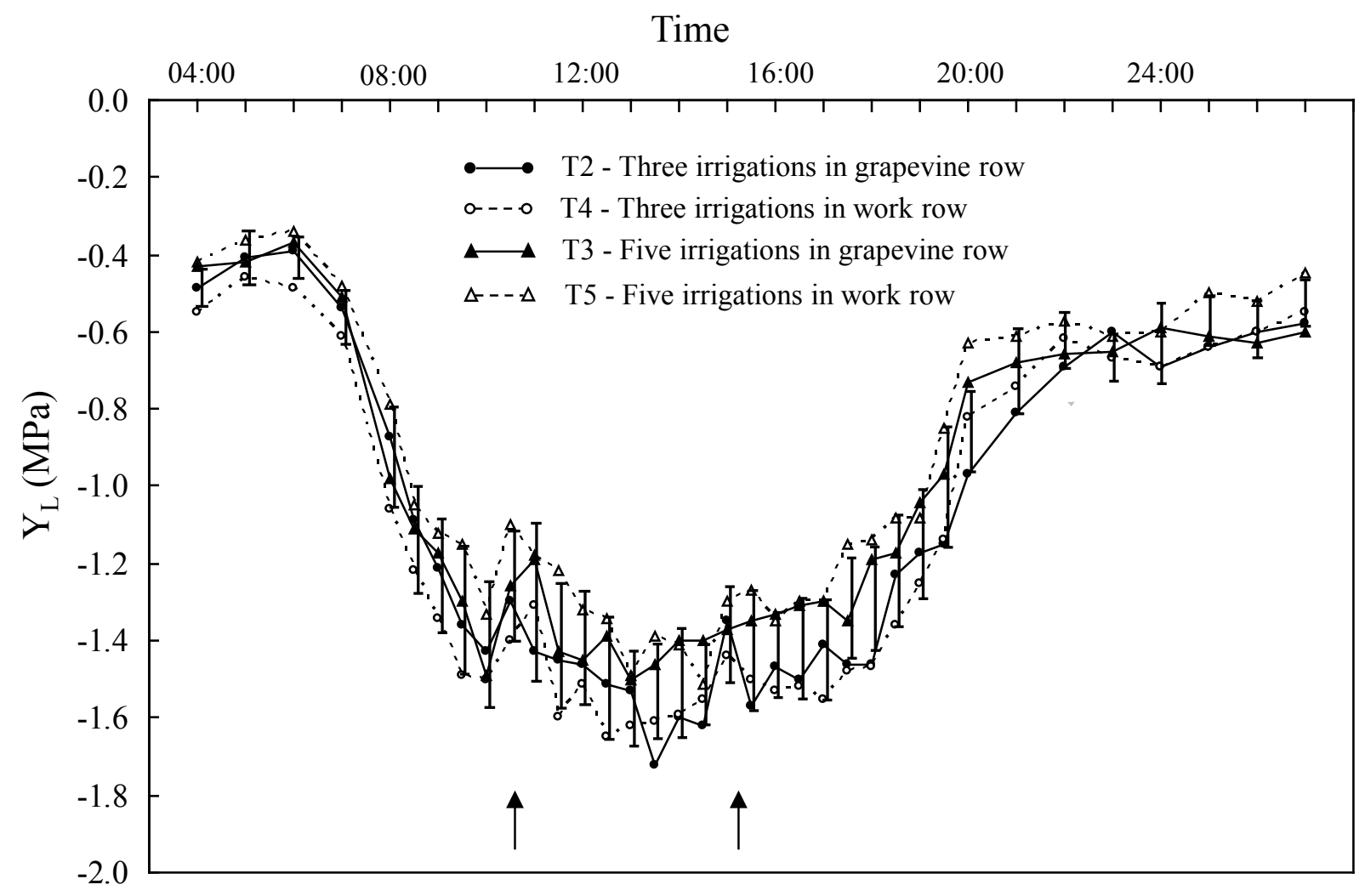

FIGURE 8

Effect of low frequency irrigation and position of dripper lines on leaf water potential $\left(\Psi_{\mathrm{L}}\right)$ in Merlot/99R as measured on 11 January 2006 near Wellington. Arrows indicate the occurrence of clouds in the morning and a veld fire in the afternoon. Vertical bars indicate the lowest significant difference $(p \leq 0.05)$. 
irrigated twice a week according to the PRD strategy were also experiencing only mild water constraints at véraison during both seasons (Table 5). Dripper lines in the work rows (T4 and T5) clearly had no effect on midday grapevine water status compared to the effect of conventional irrigation in the grapevine rows (T2 and T3).

\section{Prior to harvest}

In the 2003/04 season the non-irrigated grapevines (T1) and those that received only two irrigations before harvest (T2 and T4) experienced strong water constraints when the grapes were harvested (Table 5). This indicates that the second irrigation applied to grapevines of the T2 and T4 treatments did not improve grapevine water status compared to the non-irrigated grapevines. On the other hand, four irrigations (T3 and T5), as well as the PRD strategy (T6), caused only moderate water constraints, thereby improving grapevine water status when compared to non-irrigated conditions. The relatively high $\Psi_{\mathrm{S}}$ at harvest in the 2004/05 season compared to 2003/04 was probably caused by relatively high rainfall during January (Table 2). Nevertheless, $\Psi_{\mathrm{S}}$ trends were similar, except that the T1, T2 and T4 grapevines experienced only moderate water constraints, whereas T3, T5 and T6 showed mild water constraints. The non-irrigated grapevines and those that received two irrigations

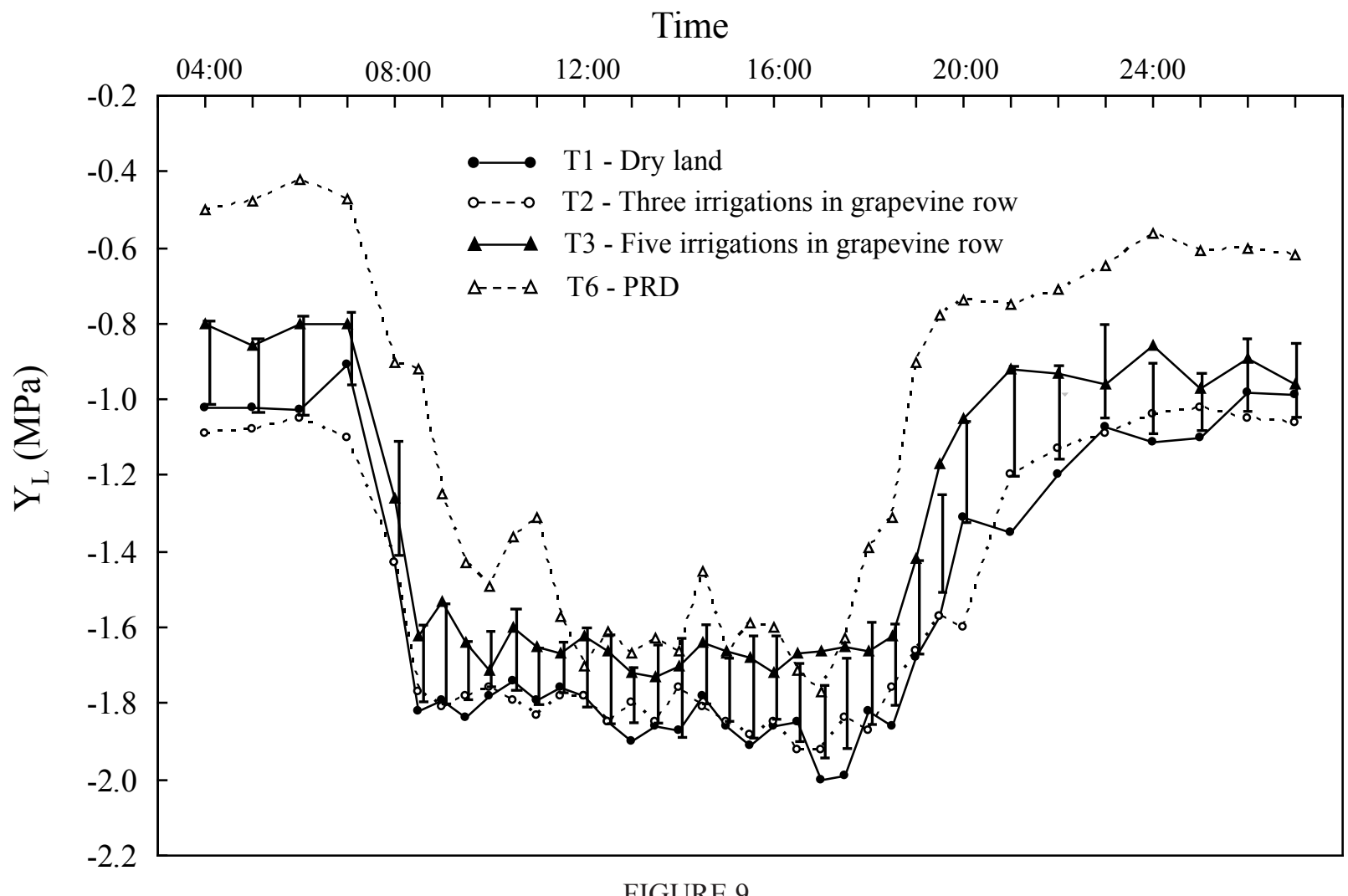

Effect of non-irrigated conditions, low frequency irrigation and partial root zone drying (PRD) on leaf water potential $\left(\Psi_{L}\right)$ in Merlot/99R as measured on 8 February 2006 near Wellington. Vertical bars indicate the lowest significant difference $(p \leq 0.05)$.

\section{TABLE 4}

Total diurnal leaf water potential $\left(\Psi_{\text {Tot }}\right)$ in Merlot/99R in response to timing of low frequency drip irrigation and partial root zone drying (PRD), as measured near Wellington at véraison (11 January) and one week before harvest (8 February) during the $2005 / 06$ season.

\begin{tabular}{|c|c|c|c|c|c|c|}
\hline \multirow[t]{3}{*}{ Date } & T1 - Non-irrigated & \multirow{2}{*}{$\begin{array}{c}\mathrm{T} 2-\text { Three } \\
\text { irrigations in } \\
\text { grapevine row }^{(1)}\end{array}$} & \multirow{2}{*}{$\begin{array}{c}\text { T3 - Five } \\
\text { irrigations in } \\
\text { grapevine row }^{(2)}\end{array}$} & \multirow{2}{*}{$\begin{array}{c}\text { T4 - Three } \\
\text { irrigations in } \\
\text { work row }^{(1)}\end{array}$} & \multirow{2}{*}{$\begin{array}{c}\text { T5 - Five } \\
\text { irrigations in } \\
\text { work row }^{(2)}\end{array}$} & \multirow[t]{2}{*}{ T6 - PRD } \\
\hline & & & & & & \\
\hline & \multicolumn{6}{|c|}{$\Psi_{\text {Tot }}\left(\mathbf{M P a}^{2}\right)$} \\
\hline 11 January & $26.5 \mathrm{a}^{(3)}$ & $22.5 \mathrm{~b}$ & $19.5 \mathrm{c}$ & $23.5 \mathrm{~b}$ & $21.0 \mathrm{bc}$ & $16.4 \mathrm{~d}$ \\
\hline 8 February & $32.3 \mathrm{a}$ & $32.3 \mathrm{a}$ & $28.0 \mathrm{~b}$ & $31.6 \mathrm{a}$ & $27.8 \mathrm{~b}$ & $22.9 \mathrm{c}$ \\
\hline
\end{tabular}

\footnotetext{
(1) Irrigations at pea size, véraison and post-harvest.

(2) Irrigations at pea size, mid-December, véraison, end January and post-harvest.

(3) Values followed by the same letter within a row do not differ significantly $(p \leq 0.05)$.
} 
TABLE 5

Effect of irrigation strategies, including partial root zone drying $(\mathrm{PRD})$, on stem water potential $\left(\Psi_{\mathrm{S}}\right)$ in Merlot/99R at véraison and harvest near Wellington.

\begin{tabular}{|c|c|c|c|c|c|c|}
\hline \multirow{2}{*}{ Season } & T1 - Non-irrigated & \multirow{2}{*}{$\begin{array}{c}\text { T2 - Three } \\
\text { irrigations in } \\
\text { grapevine row }^{(1)}\end{array}$} & \multirow{2}{*}{$\begin{array}{c}\text { T3 - Five } \\
\text { irrigations in } \\
\text { grapevine row }\end{array}$} & \multirow{2}{*}{$\begin{array}{l}\text { T4- Three } \\
\text { irrigations in } \\
\text { work row }^{(1)}\end{array}$} & \multirow{2}{*}{$\begin{array}{c}\text { T5 - Five } \\
\text { irrigations in } \\
\text { work row }^{(2)}\end{array}$} & \multirow[t]{2}{*}{ T6 - PRD } \\
\hline & & & & & & \\
\hline & \multicolumn{6}{|c|}{$\Psi_{\mathrm{S}}$ at véraison (MPa) } \\
\hline $2005 / 06$ & $-1.48 \mathrm{~d}^{(3)}$ & $-1.19 \mathrm{c}$ & $-0.97 \mathrm{ab}$ & $-1.16 b c$ & $-0.98 b$ & $-0.76 a$ \\
\hline \multirow[t]{2}{*}{$2006 / 07$} & $-1.35 \mathrm{c}$ & $-1.45 \mathrm{c}$ & $-0.51 \mathrm{a}^{(4)}$ & $-1.43 \mathrm{c}$ & $-0.48 \mathrm{a}^{(4)}$ & $-0.78 b$ \\
\hline & \multicolumn{6}{|c|}{$\Psi_{\mathrm{S}}$ at harvest (MPa) } \\
\hline $2003 / 04$ & $-1.52 \mathrm{~b}$ & $-1.43 \mathrm{ab}$ & $-1.13 \mathrm{a}$ & $-1.55 \mathrm{~b}$ & $-1.28 \mathrm{ab}$ & $-1.34 a b^{(4)}$ \\
\hline $2004 / 05$ & $-1.10 \mathrm{c}$ & $-1.12 \mathrm{c}$ & $-0.94 b$ & $-1.08 \mathrm{c}$ & $-0.98 b$ & $-0.62 \mathrm{a}$ \\
\hline $2005 / 06$ & $-1.68 \mathrm{c}$ & $-1.68 \mathrm{c}$ & $-1.49 b$ & $-1.69 \mathrm{c}$ & $-1.49 b$ & $-1.03 \mathrm{a}$ \\
\hline $2006 / 07$ & $-1.71 \mathrm{c}$ & $-1.76 \mathrm{c}$ & $-0.70 a^{(5)}$ & $-1.70 \mathrm{c}$ & $-0.80 a^{(5)}$ & $-1.18 b$ \\
\hline
\end{tabular}

(1) Irrigations at pea size, véraison and post-harvest.

${ }^{(2)}$ Irrigations at pea size, mid-December, véraison, end January and post-harvest.

(3) Values followed by the same letter within a row do not differ significantly $(\mathrm{p} \leq 0.05)$.

(4) In 2003/04, the T6 grapevines received only low frequency irrigation in alternating work rows.

(5) In 2006/07, the T3 and T5 grapevines were irrigated at the same frequency as the PRD ones.

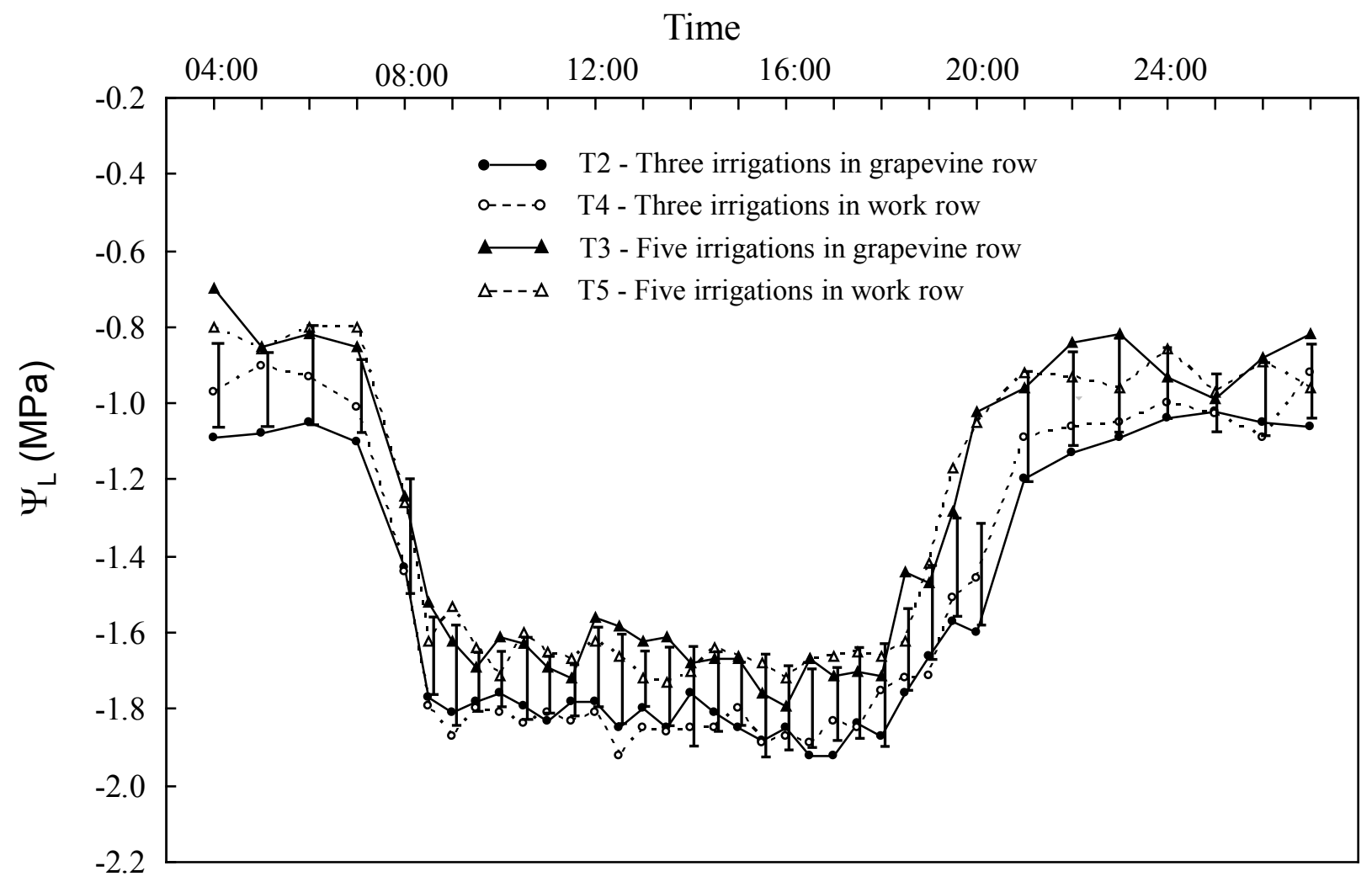

FIGURE 10

Effect of low frequency irrigation and position of dripper lines on leaf water potential $\left(\Psi_{L}\right)$ in Merlot/99R as measured on 8 February 2006 near Wellington. Vertical bars indicate the lowest significant difference $(p \leq 0.05)$. 
(T2 and T4) experienced severe water constraints when the grapes were harvested in the 2005/06 and 2006/07 seasons. Four irrigations before harvest caused strong water constraints (T3 and T5) in 2005/06, but when irrigation was applied twice a week in 2006/07 the grapevines showed only mild water constraints at harvest. When the irrigation frequency of the PRD strategy was increased during the 2005/06 and 2006/07 seasons, grapevines experienced moderate water constraints at harvest. It must be noted that the PRD grapevines experienced more water constraints than the ones that were irrigated at the same frequency in all the grapevine rows (T3) and work rows (T5) in the 2006/07 season. Hence, the low level of water constraints in the T3 and T5 grapevines clearly resulted from the higher irrigation volumes compared to the PRD grapevines (Table 1).

\section{CONCLUSIONS}

Although the level of PAW depletion of the different irrigation strategies reflected clearly in the water status of the grapevines, atmospheric conditions also influenced grapevine water status. Since $\Psi_{\mathrm{L}}, \Psi_{\mathrm{S}}$ and $\Psi_{\text {Tot }}$ were strongly related to $\Psi_{\mathrm{PD}}$, it was possible to classify grapevine water status resulting from the different irrigation strategies according to previous classifications based on $\Psi_{\mathrm{PD}}$ measurements. However, under the given conditions there was a need for a "severe" water constraint class, i.e. when $\Psi_{\mathrm{PD}}$ was below $-0.8 \mathrm{MPa}$. The nonirrigated grapevines were already subjected to moderate to strong water constraints around véraison and, except for the 2004/05 season when rain occurred during this period, they were experiencing strong to severe water constraints when the grapes were harvested. Irrigations applied at pea size berries and véraison did not seem to reduce water constraints when compared to the non-irrigated grapevines. However, this does not rule out the possibility that the cumulative water constraints in the non-irrigated grapevines from bud break until harvest were higher than in the irrigated grapevines. Dripper lines in the work rows had no effect on grapevine water status compared to conventional irrigation in the grapevine rows. Where four irrigations, and particularly the PRD strategy, were applied, the level of water constraints in the grapevines was reduced at véraison and prior to harvest compared to the non-irrigated grapevines. Given these differences, it can be assumed that the cumulative water constraints from bud break until harvest in the more frequently irrigated grapevines were appreciably lower than in the non-irrigated ones. It was evident that the low levels of water constraints in the PRD grapevines were in response to the low PAW depletion levels in the alternating work rows that were irrigated frequently. Minimal lateral flow of irrigation water occurred from the subsurface dripper lines in the work rows towards the grapevine rows under the given conditions. The effect of the different irrigation strategies on grapevine yield and wine quality is part of an ongoing study. Recommendations regarding the practical applicability of the irrigation strategies will be made on completion of the study.

\section{LITERATURE CITED}

Bonnardot, V., Carey, V., Planchon, O. \& Cautenet, S., 2001. Sea breeze mechanism and observations of its effects in the Stellenbosch wine producing area. Wynboer October 2001, 107-113.
Booysen, J.H., Steenkamp, J. \& Archer, E., 1992. Names of vertical trellising systems (with abbreviations). Wynboer, September 1992, 15.

Carbonneau, A., Deloire, A. \& Costanza, P., 2004. Leaf water potential meaning of different modalities of measurements (in French). J. Int. Sci. Vigne Vin 38, $15-19$.

Choné, X., Van Leeuwen, C., Dubourdieu, D. \& Gaudillère, J.-P, 2001. Stem water potential is a sensitive indicator of grapevine water status. Ann. Bot. 87, 477-483.

Conradie, W.J., Carey, V.A., Bonnardot, V., Saayman, D. \& Van Schoor, L.H., 2002. Effect of different environmental factors on the performance of Sauvignon blanc grapevines in the Stellenbosch/Durbanville districts of South Africa. I. Geology, soil, climate, phenology and grape composition. S. Afr. J. Enol. Vitic. 23, 78-91.

Deloire, A., Carbonneau, A., Wang, Z. \& Ojeda, H., 2004. Vine and water: a short review. J. Int. Sci. Vigne Vin 38, 1-13.

Dent, M.C., Schulze, R.E. \& Angus, G.R., 1988. Crop water requirements, deficit and water yield for irrigation planning in Southern Africa. WRC Report no. 118/1/88 and ACRU Report no. 28.

Girona, J., Mata, M., del Campo, J., Arbonés, A., Bartra, E. \& Marsal, J., 2006. The use of midday leaf water potential for scheduling deficit irrigation in vineyards. Irrig. Sci. 24, 115-127.

Greenspan, M., 2005. Integrated irrigation of California winegrapes. Prac. Vineyard \& Winery, March/April 2005, 21-79.

Grimes, D.W. \& Williams, L.E., 1990. Irrigation effects on plant water relations and productivity of Thomson Seedless grapevines. Crop Sci. 30, 255-260.

Hardie, W.J. \& Considine, J.A., 1976. Response of grapes to water-deficit stress in particular stages of development. Am. J. Enol. Vitic. 27, 55-61.

Klute, A., 1986. Water retention: Laboratory methods. In: Klute, A. (ed). Methods of soil analysis. Part 1, Physical and mineralogical methods, No. 9, Agronomy series. Madison, Wisconsin. pp. 635-662.

Laker, M.S., 2004. The effect of atmospheric and soil conditions in the grapevine water status. Thesis, Stellenbosch University, Private Bag X1, 7602 Matieland (Stellenbosch), South Africa.

Larson, R.E., Hostetler, R.P. \& Edwards, B.H., 1994. Calculus with analytic geometry. D.C. Heath and Company, Massachusetts.

Le Roux, E.G., 1974. A climate classification for the South Western Cape viticultural areas (in Afrikaans). Thesis, Stellenbosch University, Private Bag X1, 7602 Matieland (Stellenbosch), South Africa.

Medrano, H., Escalona, J., Cifre, J., Bota, J. \& Flexas, J., 2003. A ten-year study on the physiology of two Spanish grapevine cultivars under field conditions: effects of water availability from leaf photosynthesis to grape yield and quality. Func. Plant Biol. 30, 607-619.

Myburgh, P.A., 1998. Water consumption of South African vineyards: a modelling approach based on the quantified combined effects of selected viticultural, soil and meteorological parameters. Thesis, Stellenbosch University, Private Bag X1, 7602 Matieland (Stellenbosch), South Africa.

Myburgh, P.A., 2003. Responses of Vitis vinifera L. cv. Sultanina to level of soil water depletion under semi-arid conditions. S. Afr. J. Enol. Vitic. 24, 16-24.

Myburgh, P.A., 2005a. Water status, vegetative growth and yield responses of Vitis vinifera L. cvs. Sauvignon blanc and Chenin blanc to timing of irrigation during berry ripening in the Coastal region of South Africa. S. Afr. J. Enol. Vitic. 27, 1-7.

Myburgh, P.A., 2005b. Effect of altitude and distance from the Atlantic Ocean on mean February temperatures in the Western Cape coastal region. Wynboer Technical Yearbook, 2005/06, 49-52. 
Myburgh, P.A., 2007. An investigation into possible water savings using subsurface irrigation (Part II) - Plant water stress, growth, yield and quality. Wynboer Technical Yearbook, 2007/08, 38-42.

Myburgh, P.A. \& Howell, C.L., 2006. Water relations of Vitis vinifera L. $c v$. Sunred Seedless in response to soil water depletion before harvest. S. Afr. J. Enol. Vitic. 27, 196-201

Myburgh, P.A., Van Zyl, J.L. \& Conradie, W.J., 1996. Effect of soil depth on growth and water consumption of young Vitis vinifera L. $c v$. Pinot noir. S. Afr. J. Enol. Vitic. 17, 53-62.

Ojeda, H., Andary, C., Kraeva, E., Carbonneau, A. \& Deloire, A., 2002. Influence of pre- and postveraison water deficit on synthesis and concentration of skin phenolic compounds during berry growth of Vitis vinifera cv. Shiraz. Am. J. Enol. Vitic. 53, 261-267.

Olivo, N., Girona, J. \& Marsal, J., 2009. Seasonal sensitivity of stem water potential to vapour pressure deficit in grapevine. Irrig. Sci. 27, 175-182.

Patakas, A., Noitsakis, B. \& Chouzouri, A., 2005. Optimization of irrigation water use in grapevines using the relationship between transpiration and plant water status. Agric. Eco. Environ. 106, 253-259.

Pellegrino, A., Lebon, E., Voltz, M. \& Wery, J., 2004. Relationships between plant and soil water status in vine (Vitis vinifera L.). Plant and Soil 266, 129142.

Santos, T.P., Lopes, C.M., Rodrigues, M.L., De Sousa, C.R., Ricardo-Da-Silva, J.M., Maroco, J.P., Pereira, J.S. \& Chaves, M.M., 2005. Effects of partial rootzone drying irrigation on cluster microclimate and fruit composition of fieldgrown Castelão grapevines. Vitis 44, 117-125.
Scholander, P.F., Hammel, H.T., Bradstreet, E.D. \& Hemmingsen, E.A., 1965. Sap flow in vascular plants. Science 148, 339-346.

Soil Classification Working Group, 1991. Soil classification - A taxonomic system for South Africa. Memoirs on natural resources of South Africa no. 15. Dept. Agric. Developm., Private Bag X116, 0001 Pretoria, South Africa.

Sousa, T.A., Oliveira, M.T. \& Pereira, J.M., 2006. Physiological indicators of plant water status of irrigated and non-irrigated grapevines grown in a low rainfall area of Portugal. Plant and Soil 28, 127-134.

Van Zyl, J.L., 1987. Diurnal variation in grapevine water stress as a function of changing soil water status and meteorological conditions, S. Afr. J. Enol. Vitic. $8,45-52$

Van Zyl, J.L. \& Weber, H.W., 1981. The effect of various supplementary irrigation treatments on plant and soil moisture relationships in a vineyard (Vitis Vinifera var. Chenin blanc). S. Afr. J. Enol. Vitic. 2, 83-99.

Williams, L.E. \& Araujo, F.J., 2002. Correlations among predawn leaf, midday leaf and midday stem water potential and their correlations with other measures of soil and plant water status in Vitis vinifera. J. Am. Soc. Hort. Sci. 127, 448454 .

Winkel, T. \& Rambal, S., 1993. Influence of water stress on grapevines growing in the field: from leaf to whole-plant response. Aust. J. Plant Physiol. 20, 14357.

Winkler, A.J., 1962. General viticulture. University of California Press, Los Angeles. 